\title{
FAKTOR-FAKTOR YANG MEMPENGARUHI KEBIJAKAN \\ CASH HOLDING (STUDI KASUS PADA PERUSAHAAN MANUFAKTUR YANG TERDAFTAR DI BURSA EFEK INDONESIA TAHUN 2012-2015)
}

\author{
Anugerah Humendru \\ Jonner pangaribuan
}

\begin{abstract}
Abstrak
Penelitian bertujuan untuk mengetahui pengaruh Growth Opportunity, Cash Conversion Cycle dan Net Profit/Loss terhadap Cash Holding pada perusahaan manufaktur yang terdaftar di Bursa Efek Indonesia tahun 2012-2015. Rumusan masalah dalam penelitian ini adalah "Apakah Growth Opportunity, Cash Conversion Cycle dan Net Profit/Loss berpengaruh terhadap Cash Holding?". Teknik pengambilan sampel yang digunakan adalah purposive sampling dengan jumlah sampel sebanyak 15 perusahaan. Data diperoleh dari Bursa Efek Indonesia tahun 2012-2015. Teknik analisis data yang digunakan adalah regresi linier berganda dengan tingkat signifikansi sebesar 5\%. Hasil uji secara parsial menunjukkan bahwa Growth Opportunity tidak berpengaruh terhadap Cash Holding, sedangkan Cash Conversion Cycle dan Net Profit/Loss berpengaruh positif signifikan terhadap Cash Holding. Hasil uji secara simultan menunjukkan bahwa Growth Opportunity, Cash Conversion Cycle dan Net Profit/Loss berpengaruh terhadap Cash Holding. Kemampuan variabel independen dalam menjelaskan variabel dependen sebesar $22,6 \%$ sedangkan sisanya sebesar $77,4 \%$ dijelaskan oleh variabel lain di luar model penelitian ini.
\end{abstract}

Kata kunci : Cash Holding, Growth Opportunity, Cash Conversion Cycle dan Net Profit Loss

\section{PENDAHULUAN}

Berdasarkan PSAK No. 2 tahun 2009, kas terdiri dari saldo kas (cash on hand) dan rekening giro (demand deposits). Sedangkan setara kas adalah investasi yang sifatnya sangat likuid, berjangka pendek dan yang dengan cepat dijadikan kas dalam jumlah yang ditentukan. Maka kas merupakan aset lancar yang paling likuid karena kas tersebut ada secara fisik dalam bentuk uang tunai, sedangkan setara kas bukan bentuk uang tunai tetapi memiliki waktu yang singkat untuk mengubahnya ke dalam bentuk kas.

Cash Holding dapat dijelaskan menggunakan tiga teori yaitu, Trade-off Theory (Modigliani dan Miller, 1966), Agency Theory (Jensen dan Meckling, 1976) dan Pecking Order Theory (Myers dan Majluf, 1984). Pertama, Trade-off Theory menyatakan bahwa terdapat dua konsep dalam 
penahanan kas, yaitu biaya memegang kas dan manfaat yang didapatkan dari memegang kas dalam jumlah yang optimal. Kedua, Agency Theory menghubungkan tingkat kas di suatu perusahaan dengan bagian menajerial, di mana manajer pada perusahaan dengan peluang investasi rendah cenderung menahan kas daripada membayarkannya pada pemegang saham. Ketiga, Pecking Order Theory menjelaskan bahwa pembiayaan pada dasarnya berasal dari tiga sumber, yang pertama berasala dari laba ditahan. Apabila pendanaan internal ini tidak mencukupi untuk mendanai kegiatan investasi perusahaan maka akan dilanjutkan ke alternatif kedua yaitu menggunakan utang. Ketika jumlah utang yang dimiliki dirasa sudah berlebihan, pendanaan investasi dilanjutkan ke pilihan alternatif terakhir dengan mengeluarkan ekuitas Mamduh (2014).

Menurut Mai (2006) Growth Opportunity adalah peluang pertumbuhan perusahaan di masa depan. Menurut Firth et al (2008) pertumbuhan penjualan perusahaan merupakan salah satu proksi dari Growth Opportunity. Perusahaan yang memiliki pertumbuhan penjualan tinggi, berarti perusahaan tersebut memiliki Growth Opportunity yang tinggi pula. Perusahaan dengan tingkat pertumbuhan yang tinggi membutuhkan dana yang lebih banyak, sehingga perusahaan melakukan penahanan kas dalam jumlah besar untuk membiayai pertumbuhannya. Lebih jelasnya hubungan antara Growth Opportunity dengan Cash Holding dapat ditunjukkan melalui penelitian yang dilakukan oleh Opler et al. (1999) yang menunjukkan bahwa perusahaan dengan tingkat peluang pertumbuhan yang besar memegang kas dalam jumlah yang banyak.

Menurut Syarief dan Wilujeng (2009) Cash Conversion Cycle (siklus konversi kas) didefenisikan sebagai waktu dalam satuan hari yang diperlukan untuk mendapatlan kas dari hasil operasi perusahaan yang berasal dari penagihan piutang ditambah penjualan persediaan dikurangi dengan pembayaran utang. Siklus konversi kas menunjukkan seberapa cepat perusahaan menghasilkan produknya,dari membayar biaya persediaan hingga mengumpulkan kas dari konsumen dalam bentuk pembayaran atas produk jadi. Semakin lama siklus ini terjadi, semakin besar kebutuhan pendanaan internal perusahaan untuk membayar kebutuhan bahan baku perusahaan. Bigelli dan Vidal (2009) menyatakan bahwa jika perusahaan dapat mengelola siklus konversi kas mereka menjadi lebih singkat, maka mereka akan membutuhkan saldo kas dalam jumlah yang lebih kecil dibandingkan dengan perusahaan yang memiliki siklus konversi kas yang panjang. Dengan demikian, perusahaan yang memiliki siklus konversi kas yang singkat akan memegang kas dalam 
jumlah sedikit. Sebaliknya perusahaan yang memiliki siklus konversi kas yang panjang akan memegang kas dalam jumlah yang banyak.

Menurut Simamora (2000), laba bersih atau rugi bersih (Net Profit/loss) adalah perbedaan antara pendapatan dengan beban. Jika pendapatan melebihi beban, maka hasilnya adalah laba bersih. Di lain pihak, manakala beban melampaui pendapatan, maka yang muncul adalah rugi bersih. Pendapatan akan mendongkrak aktiva perusahaan atau ekuitas pemegang saham sedangkan beban mengkonsumsi aktiva bersih perusahaan.Horngren et al. (1994) menyatakan, laba bersih mengukur kemampuan usaha untuk menghasilkan laba dan menjawab pertanyaan bagaimana keberhasilan perusahaan mengelola usahanya. Perusahaan yang mengalami laba menunjukkan kinerja perusahaan yang berada pada kondisi yang baik dan mencerminkan bahwa perusahaaan juga memiliki peluang bertumbuh. Sebaliknya perusahaan yang mengalami rugi menunjukkan kinerja perusahaan yang berada pada kondisi yang kurang baik dan mencerminkan bahwa perusahaaan juga cenderung tidak memiliki peluang bertumbuh. Telah dijelaskan bahwa perusahaan yang memilikipeluang bertumbuh memegang kas dalam jumlah yang banyak untuk membiayai pertumbuhannya. Dengan demikian perusahaan yang mengalami laba memegang kas dalam jumlah banyak, sedangkan perusahaan mengalami rugi cenderung memegang kas dalam jumlah sedikit.

Penelitian ini bermaksud untuk mereplikasi penelitian yang dilakukan oleh William dan Fauzi (2013) yang berjudul "Analisis pengaruh Growth Opportunity, Net Working Capital dan Cash Conversion Cycle terhadap Cash Holdings perusahaan sektor pertambangan yang terdaftar di Bursa Efek Indonesia periode 2009-2011”. Berbeda dengan penelitian William dan Fauzi (2013), objek dari penelitian ini adalah perusahaan manufaktur yang terdaftar di Bursa Efek Indonesia periode 2012-2015. Selain objek penelitian yang berbeda, peneliti juga mengurangi variabel Net Working Capital dan menambahkan satu variabel baru yaitu Net Profit/Loss.

Berdasarkan penjelasan teori diuraikan di atas maka peneliti tertarik untuk melakukan penelitian dengan judul "Faktor-faktor yang mempengaruhi kebijakan Cash Holding". Rumusan masalah dalam penelitian ini adalah"Apakah Growth Opportunity, Cash Conversion Cycle dan Net Profit/Loss berpengaruh terhadap Cash Holding?" 


\section{TINJAUAN PUSTAKA DAN HIPOTESIS}

\section{Trade-off Theory}

Pada pasar modal yang sempurna, tidak akan ada biaya transaksi dalam meningkatkan jumlah kas dan memegang aset lancar tidak akan berpengaruh pada nilai perusahaan. Namun pada kenyataannya pasar modal jauh kata sempurna dan terdapat biaya transaksi yang tidak relevan (Bigelli dan Vidal, 2009). Oleh karena itulah perusahaan harus berhati-hati dalam menentukan tingkat Cash Holding yang optimal.

Berdasarkan teori ini, menilai Cash Holding yang optimal yaitu dengan mempertimbangkan biaya yang ditimbulkan dari memegang kas tersebut dengan manfaat yang akan didapatkan perusahaan. Menurut Ferreira dan Vilela (2004), manfaat utama yang bisa didapatkan perusahaan dengan memegang kas di antaranya mengurangi kemungkinan terjadinya financial distress, memungkinkan terpenuhinya kebijakan investasi meskipun adanya kendala keuangan, dan meminimalkan biaya atas adanya pendanaan eksternal atau terjadinya likuidasi aset. Sementara itu, biaya yang harus dikeluarkan perusahaan untuk memegang kas adalah opportunity cost dari modal yang diinvestasikan pada aset lancar dengan return yang kecil. Opler (1999) menyatakan bahwa manajemen yang ingin memaksimalkan kesejahteraan para pemegang sahamnya harus mengatur Cash Holding perusahaan pada tingkat dimana manfaat memegang kas setara atau bahkan melebihi biaya yang harus dikeluarkan perusahaan untuk memegang kas tersebut.

\section{Agency Theory}

Teori ini menjelaskan hubungan antara prinsipal, dalam hal ini pemegang saham, dan agen-agen, seperti manajer. Dalam hubungan ini, p1,25 cmemegang saham menyerahkan wewenang mereka kepada manajer untuk mengelola aset-aset perusahaan agar bisa memberikan profit untuk mereka. Adanya pendelegasian wewenang ini bisa menimbulkan permasalahan. Terdapat dua permasalahan dalam agency theory, yaitu adanya permasalahan yang muncul ketika keinginan atau tujuan dari pemegang saham dan manajer berbeda dan pemegang saham yang tidak dapat melakukan pengecekan atau pengawasan tentang apa yang sebenarnya dilakukan para manajer tersebut dikarenakan sulitnya mengakses informasi ke arah sana atau mahalnya biaya untuk melakukan hal tersebut. 
Dalam sebuah perusahaan, adanya kelebihan arus kas cenderung diinvestasikan dalam hal-hal yang tidak ada kaitannya dengan kegiatan utama perusahaan. Hal inilah yang menyebabkan terjadinya perbedaan kepentingan karena pemegang saham ingin investasi dengan return yang tinggi tentunya dengan risiko yang harus dipikul juga tinggi sementara pihak manajerial memilih investasi dengan return yang rendah. Daher (2010) menyatakan bahwa manajer lebih memilih untuk mengumpulkan kas tanpa adanya peluang investasi daripada membayarkannya kepada para pemegang saham.

\section{Pecking Order Theory}

Belawanan dengan trade-off theory, pecking order theory menganggap bahwa tidak ada tingkat Cash Holding yang optimal tetapi kas memiliki peran sebagai penyangga antara laba ditahan dan kebutuhan investasi. Kas akan tersedia ketika profit yang dihasilkan perusahaan melebihi kebutuhan investasinya. Ketika kas tersedia dalam jumlah yang berlebih dan perusahaan yakin akan profitabilitas investasi mereka, maka kelebihan kas akan dibayarkan kepada para pemegang saham dalam bentuk dividen (Myers dan Majluf, 1984).

\section{Cash Holding}

Berdasarkan PSAK No. 2 tahun 2009, kas terdiri dari saldo kas (cash on hand) dan rekening giro (demand deposits). Sedangkan setara kas adalah investasi yang sifatnya sangat likuid, berjangka pendek dan yang dengan cepat dapat dijadikan kas dalam jumlah yang dapat ditentukan dan memiliki resiko perubahan nilai yang tidak signifikan. Kas merupakan bentuk aktiva yang paling likuid, karena sifatnya yang likuid tersebut, membuat kas memiliki tingkat keuntungan yang paling rendah dibandingkan apabila kas tersebut diinvestasikan dalam bentuk aset lain yang lebih menguntungkan, seperti misalnya deposito berjangka, membeli obligasi perusahaan lain, dan sebagainya. Oleh karena itu, ketersediaan jumlah kas yang optimal bagi perusahaan dapat mempengaruhi keuntungan yang didapatkan oleh perusahaan tersebut. Apabila jumlah kas tersebut terlalu banyak, akan berdampak pada keuntungan yang bisa didapatkan perusahaan atas setiap peluang investasi yang terlewatkan. Namun apabila jumlah terlalu sedikit juga akan berpengaruh pada likuiditas perusahaan.Dengan tersedianya kas dalam jumlah yang cukup, perusahaan tidak harus mengorbankan kesempatan investasi yang dimilikinya untuk mempertahankan likuiditasnya. 
Menurut Teruel et al. (2009) dalam Wijaya (2010), Cash Holding merupakan rasio yang membandingkan antara jumlah kas dan setara kas yang dimiliki perusahaan dengan jumlah aktiva perusahaan secara keseluruhan.Ukuran yang digunakan untuk menghitung nilai Cash Holding adalah sebagai berikut :

$$
\text { Cash Holding }=\frac{\text { Kas+Setara Kas }}{\text { Total Aset }}
$$

\section{Growth Opportunity}

Menurut Mai (2006) Growth Opportunity adalah peluang pertumbuhan perusahaan di masa depan. Pertumbuhan perusahaan menggambarkan tolok ukur keberhasilan perusahaan.Keberhasilan tersebut juga menjadi tolok ukur investasi untuk pertumbuhan pada masa yang akan datang.

Ukuran yang digunakan untuk menghitung nilai Growth Opportunity adalah sebagai berikut :

$$
\text { Growth Opportunity }=\frac{\text { Penjualan T-Penjualan (T-1) }}{\text { Penjualan (T-1) }}
$$

Keterangan :

- Penjualan $\mathrm{T}=$ Penjualan tahun berjalan

- Penjualan T-1 = Penjualan tahun sebelumnya

\section{Cash Conversion Cycle}

Menurut Syarief dan Wilujeng (2009) Cash Conversion Cycle (siklus konversi kas) didefenisikan sebagai waktu dalam satuan hari yang diperlukan untuk mendapatkan kas dari hasil operasi perusahaan yang berasal dari penagihan piutang ditambah penjualan persediaan dikurangi dengan pembayaran utang.

Ukuran yang digunakan untuk menghitung Cash Conversion Cylce adalah sebagai berikut :

$$
\begin{aligned}
& \text { Cash Conversion Cylce }=\text { Days Inventory }+ \text { Days Receivable }- \\
& \text { Days Inventory }=\frac{365}{\text { Inventory Turnover }} \\
& \text { Inventory Turnover }=\frac{\mathrm{HPP}}{\text { Persediaan Rata-rata }} \\
& \text { Days Receivable }=\frac{365}{\text { Account Receivable Turn Over }}
\end{aligned}
$$




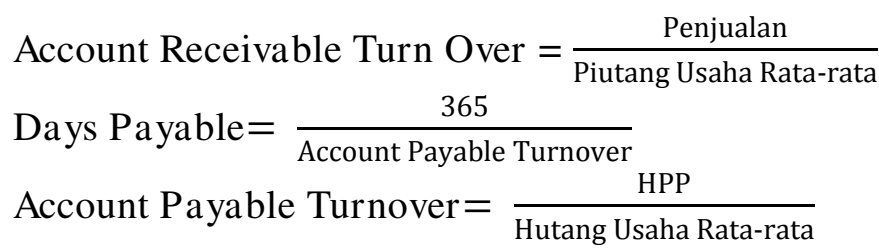

\section{Net Profit/Loss}

Menurut Simamora (2000), laba bersih atau rugi bersih (Net Profit/Loss) adalah perbedaan antara pendapatan dengan beban. Jika pendapatan melebihi beban, maka hasilnya adalah laba bersih. Di lain pihak, manakala beban melampaui pendapatan, maka yang muncul adalah rugi bersih. Pendapatan akan mendongkrak aktiva perusahaan atau ekuitas pemegang saham sedangkan beban mengkonsumsi aktiva bersih perusahaan.

\section{Pengaruh Growth Opportunity terhadap Cash Holding}

Berdasarkan Trade-off Theory, menilai Cash Holding yang optimal yaitu dengan mempertimbangkan biaya yang ditimbulkan dari memegang kas tersebut dengan manfaat yang akan didapatkan perusahaan. Artinya, apabila manfaat yang didapatkan perusahaan lebih besar daripada biaya yang ditimbulkan dari memegang kas maka perusahaan cenderung menahan kas dalam jumlah banyak. Perusahaan dengan tingkat pertumbuhan yang tinggi akan melakukan penahanan kas dalam jumlah besar untuk membiayai pertumbuhannya, karena manfaat yang didapatkan perusahaan lebih besar daripada biaya yang ditimbulkan dari memegang kas.

\section{Pengaruh Cash Conversion Cycle terhadap Cash Holding}

Siklus konversi kas menunjukkan seberapa cepat perusahaan menghasilkan produknya, dari membayar biaya persediaan hingga mengumpulkan kas dari konsumen dalam bentuk pembayaran atas produk jadi. Semakin lama siklus ini terjadi, semakin besar kebutuhan pendanaan internal perusahaan untuk membayar kebutuhan bahan baku perusahaan.

Menurut Pecking Order Theory, perusahaan memprioritaskan untuk menggunakan pembiayaan internal sebagai pilihan yang pertama dalam membiayai kegiatan operasionalnya. Pembiayaan internal ini dipilih menjadi pilihan pertama karena pembiayaan ini lebih murah dan tidak berisiko. Artinya, perusahaan cenderung menahan kas daripada menerbitkan hutang atau saham. 
Dengan demikian, semakin lama siklus konversi kas maka semakin besar juga kebutuhan pendanaan internal sehingga perusahaan cenderung menahan kas dalam jumlah besar.

\section{Pengaruh Net Profit/Loss terhadap Cash Holding}

Seperti telah dijelaskan bahwa berdasarkan Trade-off Theory, menilai Cash Holding yang optimal yaitu dengan mempertimbangkan biaya yang ditimbulkan dari memegang kas tersebut dengan manfaat yang akan didapatkan perusahaan. Artinya, apabila manfaat yang didapatkan perusahaan lebih besar daripada biaya yang ditimbulkan dari memegang kas maka perusahaan cenderung menahan kas dalam jumlah banyak.

\section{Kerangka Berpikir}

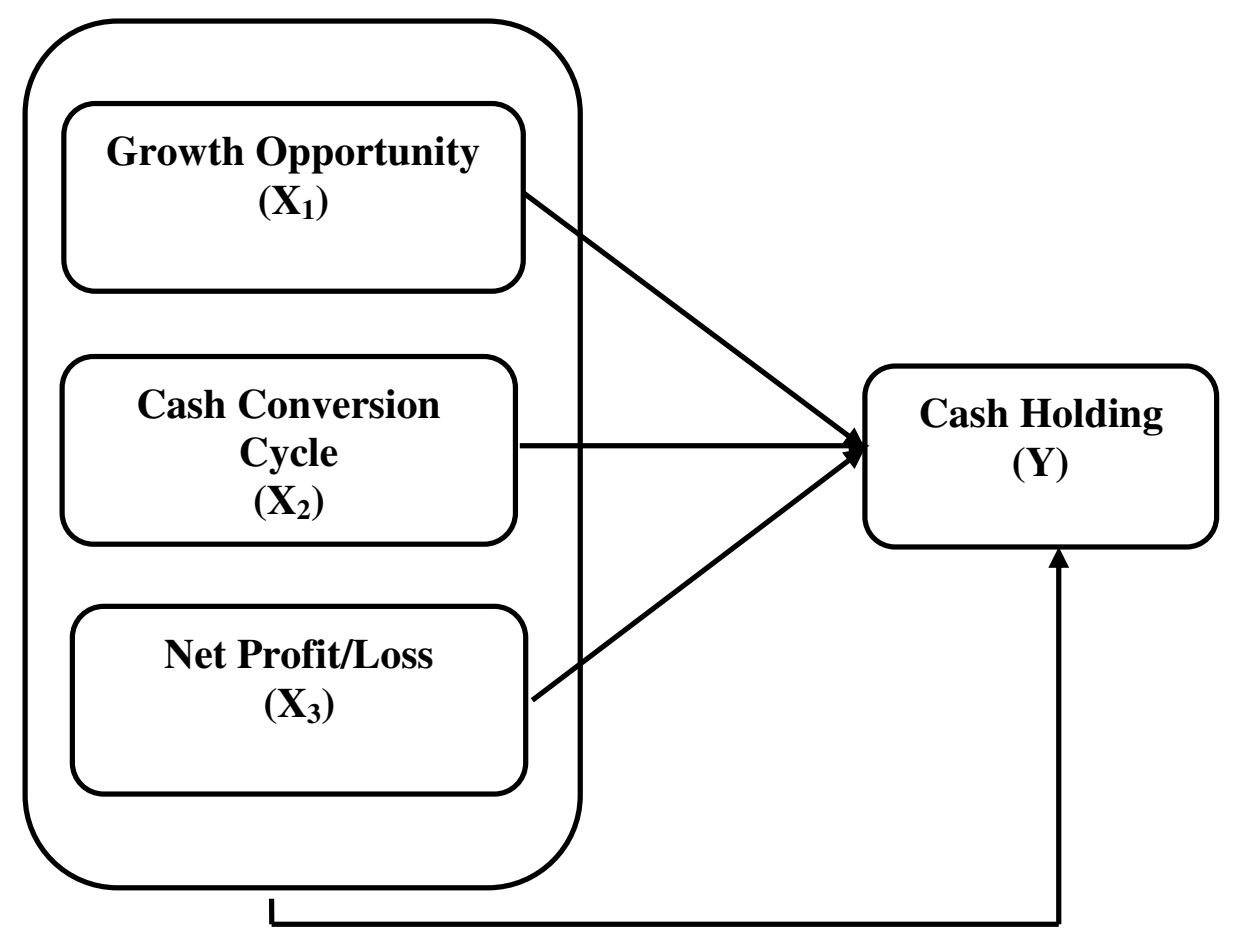




\section{Hipotesis}

Berdasarkan perumusan masalah dan kajian empiris yang telah dilakukan sebelumnya, maka hipotesis yang diajukan dalam penelitian ini adalah :

$\mathrm{H}_{1}$ :Growth Opportunity berpengaruh positif signifikan terhadap Cash Holding.

$\mathrm{H}_{2}$ :Cash Conversion Cycle berpengaruh positif signifikan terhadap Cash Holding.

$\mathrm{H}_{3}$ :Net Profit/Loss berpengaruhpositif signifikan terhadap Cash Holding.

$\mathrm{H}_{4}$ :Growth Opportunity,Cash Conversion Cycle, Net Profit/Loss

berpengaruh signifikan secara simultan terhadap Cash Holding.

\section{METODE PENELITIAN}

\section{Ruang Lingkup Penelitian}

Ruang lingkup penelitian membahas mengenai pengaruh Growth Opportunity, Cash Conversion Cycle dan Net Profit/Loss terhadap Cash Holdingpada perusahaan manufaktur kelompok Makanan dan Minuman yang terdaftar di Bursa Efek Indonesia periode 2012-2015.

\section{Populasi dan Sampel}

Populasi yang digunakan dalam penelitian ini adalah perusahaan manufaktur yang telah terdaftar di Bursa Efek Indonesia periode 20122015.

Sampel penelitian dipilih dengan menggunakan pendekatan purposive sampling. Sampel dipilih berdasarkan kriteria, maksud dan tujuan tertentu. . Kriteria yang digunakan dalam pengambilan sampel ini adalah :

1. Perusahaan termasuk kategori perusahaan manufaktur kelompok Makanan dan Minuman.

2. Perusahaan menerbitkan laporan keuangan 31 Desember yang telah diaudit periode 2012-2015

Berdasarkan kriteria di atas, maka diperoleh sampel berjumlah 15 perusahaan. Berikut sampel penelitian. 


\section{Operasionalisasi Variabel \\ Cash Holding}

Cash Holding merupakan rasio yang membandingkan antara jumlah kas dan setara kas yang dimiliki perusahaan dengan jumlah aktiva perusahaan secara keseluruhan.Ukuran yang digunakan untuk menghitung nilai Cash Holding adalah sebagai berikut :

\section{Growth Opportunity}

$$
\text { Cash Holding }=\frac{\text { Kas+Setara Kas }}{\text { Total Aset }}
$$

Growth Opportunity adalah peluang pertumbuhan perusahaan di masa depan. Pertumbuhan perusahaan menggambarkan tolok ukur keberhasilan perusahaan.Keberhasilan tersebut juga menjadi tolok ukur investasi untuk pertumbuhan pada masa yang akan datang. Ukuran yang digunakanuntuk menghitung nilai Growth Opportunity adalah sebagai berikut :

\section{Cash Conversion Cycle}

$$
\text { Growth Opportunity }=\frac{\text { Penjualan T-Penjualan }(\mathrm{T}-1)}{\text { Penjualan }(\mathrm{T}-1)}
$$

Cash Conversion Cycle (siklus konversi kas) didefenisikan sebagai waktu dalam satuan hari yang diperlukan untuk mendapatkan kas dari hasil operasi perusahaan yang berasal dari penagihan piutang ditambah penjualan persediaan dikurangi dengan pembayaran utang.

$$
\begin{aligned}
& \text { Cash Conversion Cylce }=\text { Days Inventory }+ \text { Days Receivable - } \\
& \text { Days Inventory }=\frac{365 \text { Days Payable }}{\text { Inventory Turnover }} \\
& \text { Inventory Turnover }=\frac{\text { HPP }}{\text { Persediaan Rata-rata }} \\
& \text { Days Receivable }=\frac{365}{\text { Account Receivable Turn Over }} \\
& \text { Account Receivable Turn Over }=\frac{\text { Penjualan }}{\text { Piutang Usaha Rata-rata }} \\
& \text { Days Payable }=\frac{365}{\text { Account Payable Turnover }} \\
& \text { Account Payable Turnover }=\frac{\text { HPP }}{\text { Hutang Usaha Rata-rata }}
\end{aligned}
$$




\section{Net Profit/Loss}

Laba bersih atau rugi bersih (Net Profit/Loss) adalah perbedaan antara pendapatan dengan beban.Variabel Net Profit/Loss merupakan variabel berskala ukuran non-metrik atau kategori.Jika variabel independen berukuran kategori, maka dalam model regresi variabel tersebut harus dinyatakan sebagai veriabel dummy dengan memberi kode 1 (satu) atau 0 (nol) (Ghozali, 2006). Dengan demikian, apabila perusahaan mengalami laba maka diberi kode 1 (satu), sebaliknya apabila rugi diberi kode 0 (nol).

\section{Teknik Analisis Data}

Metode analisis yang digunakan pada penelitian ini adalah analisis regresi linear berganda.Analisis regresi linear berganda digunakan untuk menguji pengaruh Growth Opportunit, Cash Conversion Cycle dan Net Profit/Loss terhadap Cash Holding pada perusahaan manufaktur kelompok Makanan dan Minuman yang terdaftar di Bursa Efek Indonesia periode 2012-2015.

Sebelum dilakukan analisis regresi linear berganda, terlebih dahulu akan dilakukan uji asumsi klasik. Berikut ini penjelasan terperinci mengenai metode analisis dalam penelitian ini.

\section{Uji Asumsi Klasik}

Uji asumsi klasik dilakukan untuk memastikan bahwa sampel yang diteliti terhindar dari gangguan normalitas, multikolonieritas, autokorelasi dan heteroskedastisitas.

Persamaan regresi yang digunakan dalam penelitian ini adalah:

$$
\mathbf{Y}=\mathbf{a}+\mathbf{b}_{1} \mathbf{X}_{1}+\mathbf{b}_{2} \mathbf{X}_{2}+\mathbf{b}_{3} \mathbf{X}_{3}+\mathbf{e}
$$

Di mana :

$$
\begin{array}{ll}
\mathbf{Y} & =\text { Cash Holding } \\
\mathbf{a} & =\text { Kostanta }
\end{array}
$$

$\mathbf{b}_{\mathbf{1}}, \mathbf{b}_{\mathbf{2}}, \mathbf{b}_{\mathbf{3}}, \mathbf{b}_{\mathbf{4}}=$ Koefisien regresi

$\mathbf{X}_{\mathbf{1}} \quad=$ Growth Oppurtunity

$\mathbf{X}_{\mathbf{2}}=$ Cash Conversion Cycle

$\mathbf{X}_{3}=$ Net Profit $/$ Loss

e $\quad=$ Error Term 


\section{HASIL PENELITIAN DAN PEMBAHASAN}

\section{Uji Asumsi Klasik}

\section{Uji normalitas}

Uji asumsi klasik dilakukan untuk memastikan bahwa sampel yang diteliti terhindar dari gangguan normalitas, multikolonieritas, autokorelasi dan heteroskedastisitas.

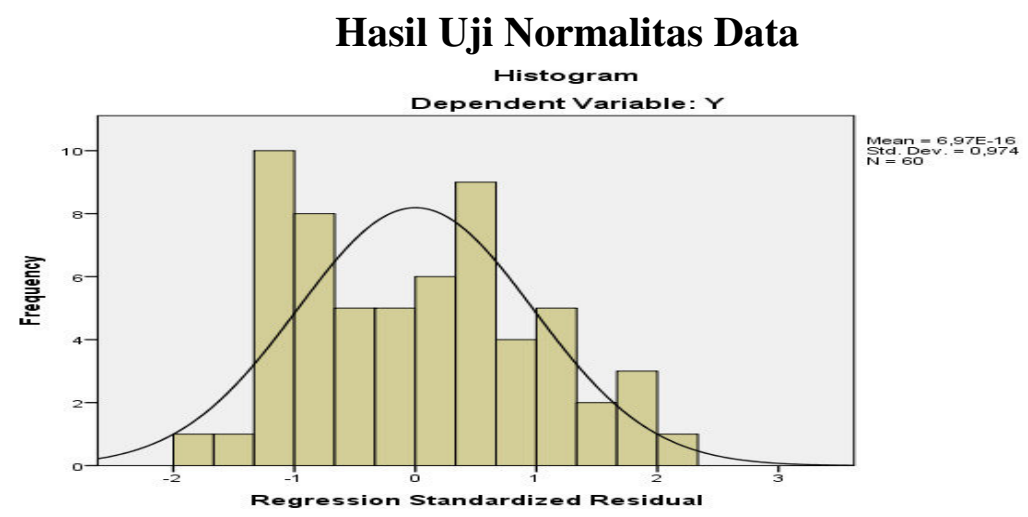

Sumber : Hasil Output SPSS 20 (data diolah)

Berdasarkan grafik histogram di atas dapat dilihat bahwa gambar histogram telah berbentuk lonceng dan tidak melenceng ke kanan atau ke kiri yang menunjukkan bahwa data telah terdistribusi secara normal.

Selain uji grafik histogram, normalitas data juga dapat dideteksi melalui pengamatan normal P-P Plot of Regression Standardized Residual. Pada grafik P-P Plot, sebuah data dikatakan berdistribusi normal apabila titik-titik datanya tidak melenceng kekiri atau kekanan, melainkan menyebar tidak jauh disekitar garis diagonal. Seperti pada di bawah ini,terlihat bahwa titik-titik variabel berada disekitar garis $\mathrm{Y}=\mathrm{X}$ atau data menyebar disekitar garis diagonal serta penyebarannya megikuti arah garis diagonal, ini menunjukkan bahwa data telah terdistribusi normal. 


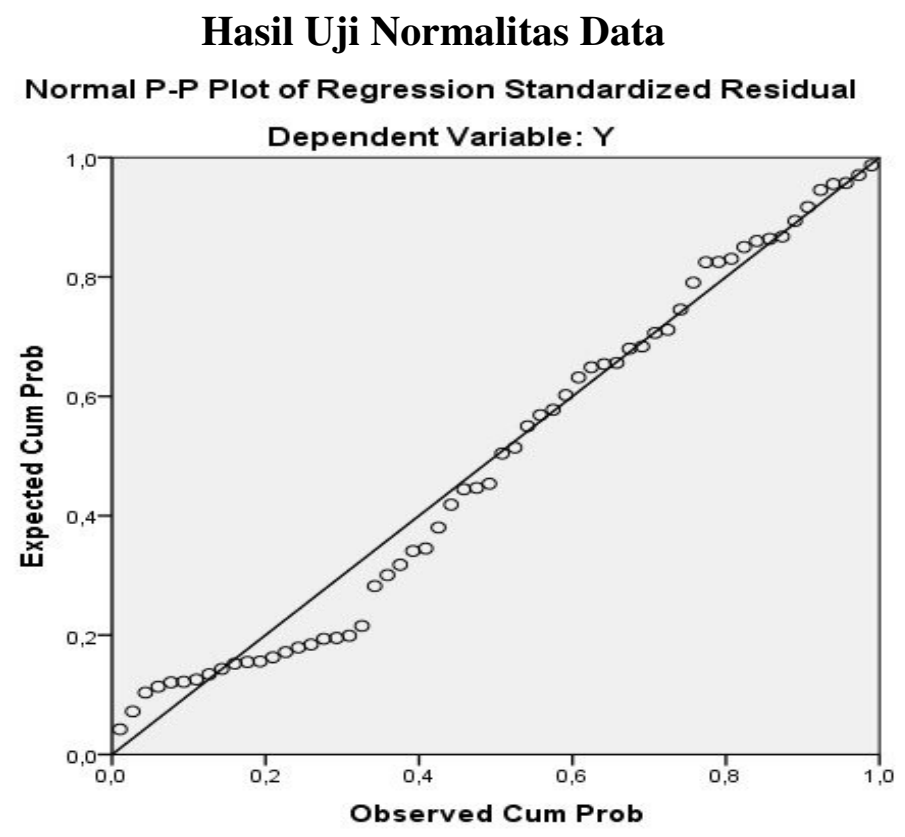

Sumber : Hasil Output SPSS 20 (data diolah)

\section{Uji Multikolinearitas}

Uji multikolinearitas bertujuan untuk menguji apakah model regresi ditemukan adanya korelasi antar variabel independen (Ghozali,2006). Model regresi yang baik seharusnya tidak terjadi korelasi di antara variabel independen. Jika variabel independen saling berkorelasi, maka variabelvariabel ini tidak ortogonal (variabel independen yang nilai korelasi antar sesama variabel independen sama dengan nol).

Dalam mendeteksi ada atau tidaknya multikolonieritas di dalam model regresi dapat dilihat dari nilai tolerance dan variance inflation factor (VIF). Kedua ukuran ini menunjukkan setiap variabel independen manakah yang dijelaskan oleh variabel independen lainnya. Tolerance mengukur variabilitas variabel independen yang dipilih yang tidak dijelaskan oleh variabel independen lainnya. Jadi nilai tolerance yang rendah sama dengan nilai VIF tinggi. Nilai cut off yang umum dipakai untuk menunjukkan adanya multikolonieritas adalah nilai tolerance $\leq 0,10$ atau sama dengan nilai VIF $\geq 10$ (Ghozali, 2006).Hasil Uji Multikolonieritas ditunjukkan pada tabel berikut: 
Coefficients $^{\mathrm{a}}$

\section{Hasil Uji Multikolinearitas}

\begin{tabular}{|c|c|c|c|c|c|}
\hline \multirow[t]{2}{*}{ Model } & \multicolumn{2}{|c|}{$\begin{array}{l}\text { Unstandardized } \\
\text { Coefficients }\end{array}$} & \multirow{2}{*}{$\begin{array}{c}\begin{array}{c}\text { Standardized } \\
\text { Coefficients }\end{array} \\
\text { Beta }\end{array}$} & \multicolumn{2}{|c|}{ Collinearity Statistics } \\
\hline & $B$ & Std. Error & & Tolerance & VIF \\
\hline (Constant) &,- 034 & ,048 & & & \\
\hline $\mathrm{X} 1$ & 022 & ,057 & ,047 & ,929 & 1,076 \\
\hline $\mathrm{X} 2$ & ,001 & ,000 & ,412 & ,954 & 1,048 \\
\hline X3 & ,106 & ,044 & ,286 & ,957 & 1,045 \\
\hline
\end{tabular}

a. Dependent Variable: $Y$

Sumber : Hasil Output SPSS 20 (data diolah)

Berdasarkan hasil uji multikolonieritas, nilai VIF variabel independen yaitu Growth Opportunity, Cash Conversion Cycle danNet Profit/Loss di bawah nilai 10 dan nilai tolerance variabel lebih besar dari 0,10 . Dengan demikian, dapat disimpulkan bahwa tidak ada masalah multikolinieritas antar variabel independen dan model regresi.

\section{Uji Autokorelasi}

Uji autokorelasi bertujuan menguji apakah dalam model regresi linear ada korelasi antara kesalahan pengganggu pada periode $t$ dengan kesalahan pengganggu pada periode t-1(sebelumnya) (Ghozali,2006). Dalam penelitian ini, uji autokorelasi dilakukan dengan menggunakan uji Durbin- Waston (DW test). Untuk pengambilan keputusan ada tidaknya autokorelasi disesuaikan dengan tabel

keputusan hipotesis sebagai berikut :

\section{Tabel Hipotesis}

\begin{tabular}{|l|c|c|}
\hline \multicolumn{1}{|c|}{ Hipotesis nol } & Keputusan & Jika \\
\hline Tidak ada autokorelasi positif & Tolak & $0<\mathrm{d}<\mathrm{dl}$ \\
\hline Tidak ada autokorelasi positif & No decision & $\mathrm{dl} \leq \mathrm{d} \leq \mathrm{du}$ \\
\hline Tidak ada autokorelasi negatif & Tolak & $4-\mathrm{dl}<\mathrm{d}<4$ \\
\hline Tidak ada autokorelasi negatif & No decision & $4-\mathrm{du} \leq \mathrm{d} \leq 4-\mathrm{dl}$ \\
\hline $\begin{array}{l}\text { Tidak ada autokorelasi, positif } \\
\text { atau negatif }\end{array}$ & Tidak ditolak & $\mathrm{du}<\mathrm{d}<4-\mathrm{du}$ \\
\hline
\end{tabular}


Hasil Uji Autokorelasi

Model Summary ${ }^{\mathrm{b}}$

\begin{tabular}{|l|r|r|r|r|r|}
\hline Model & $\mathrm{R}$ & $\mathrm{R}$ Square & \multicolumn{1}{c|}{$\begin{array}{c}\text { Adjusted R } \\
\text { Square }\end{array}$} & $\begin{array}{c}\text { Std. Error of the } \\
\text { Estimate }\end{array}$ & Durbin-Watson \\
\hline 1 &, $475^{\mathrm{a}}$ &, 226 &, 184 &, 108248 & 1,914 \\
\hline
\end{tabular}

a. Predictors: (Constant), X3, X2, X1

b. Dependent Variable: $Y$

Sumber : Hasil Output SPSS 20 (data diolah)

Hasil uji Durbin-Watson menunjukkan besaran nilai DW sebesar 1,928. Nilai ini dibandingkan dengan nilai Durbin-Watson $(k, n)$ dengan $k$ menunjukkan jumlah variabel independen, yaitu 3, dan $n$ adalah jumlah sampel yang berjumlah 60. Apabila nilai d yang didapat tergolong pada jarak nilai du $<$ DW $<4$-du, dikatakan tidak ada autokorelasi positif atau negatif. Nilai du $=1,689, \mathrm{DW}=1,928$ sehingga $1,689<1,914<2,311$. Hasil tersebut menunjukkan bahwa model yang digunakan tidak ada autokorelasi positif maupun negatif (bebas uji autokorelasi).

\section{Uji Heteroskedastisitas}

Pengujian ini bertujuan untuk menguji apakah terjadi ketidaksamaan varian dan residual satu pegamatan ke pengamatan lain dalam model regresi. Model penelitian yang baik yaitu homoskedastisitas, yaitu varian dan residual satu pengamatan yang lain hasilnya tetap. Terdapat beberapa cara untuk mengetahui adanya heteroskedastisitas yang menunjukkan bahwa model peneltian yang kurang layak. Dalam penelitian ini digunakan diagram titik (scatterplot) yang seharusnya titik-titik tersebut tersebar acak agar tidak terdapat heteroskedastisitas.

Adapun hasil uji heteroskedastisitas dalam penelitian ini disajikan pada gambar berikut. 


\section{Hasil Uji heteroskedastisitas}

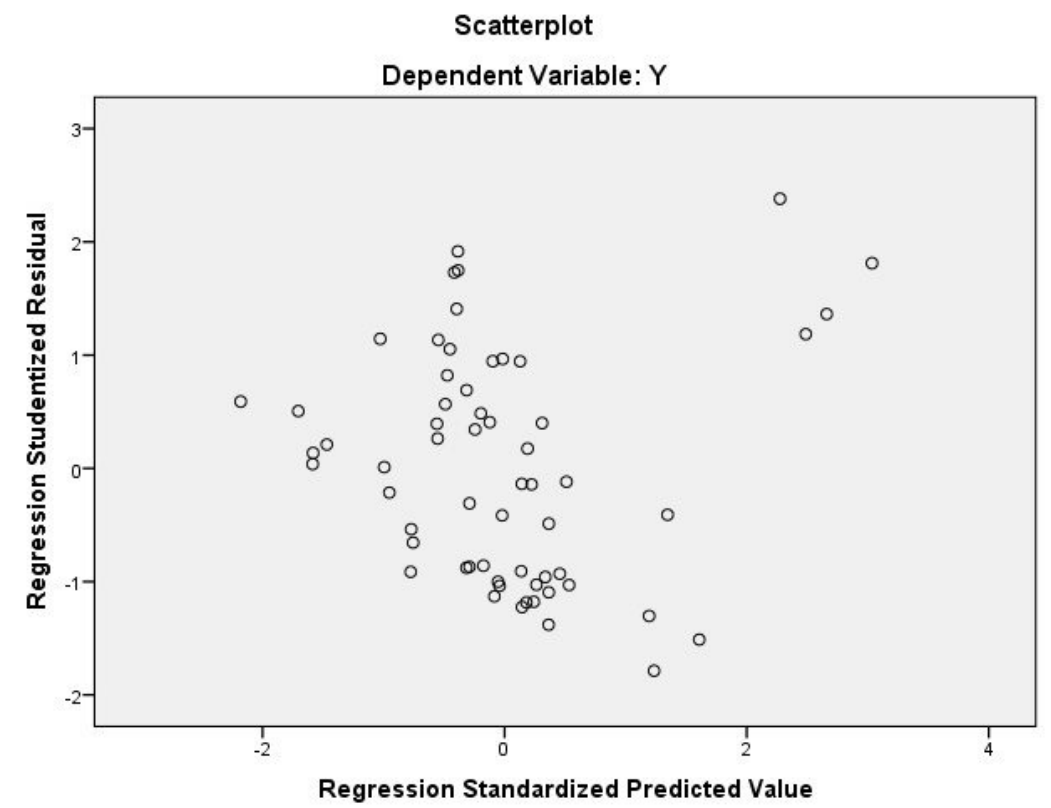

Sumber : Hasil Output SPSS 20 (data diolah)

Dengan melihat grafik scatterplot, terlihat titik-titik menyebar secara cak, serta tersebar dengan baik diatas maupun dibawah angka 0 pada sumbu Y. Maka dapat dapak diambil kesimpulan bahwa tidak terdapat gejala heteroskedastisitas pada model regresi yang digunakan.

\section{Analisis Regresi Linier Berganda}

Analisis regresi digunakan untuk mengukur kekuatan hubungan antara dua variabel atau lebih. Analisis ini juga dapat menunjukkan arah hubungan antara variabel dependen dan variabel independen (Ghozali, 2006). Dalam penelitian ini, analisis regresi linear berganda digunakan untuk mengetahui ada tidaknya pengaruh Growth Opportunity, Cash Conversion Cycle, Net Profit/Loss terhadap Cash Holding pada perusahaan manufaktur kelompok Makanan dan Minuman yang terdaftar di Bursa Efek Indonesia periode 2012-2015.Hasil analisis regresi linear berganda ditunjukkan pada tabel berikut : 
Hasil Analisis Regresi Linear Berganda

Coefficients $^{\mathrm{a}}$

\begin{tabular}{|l|r|r|r|r|r|}
\hline Model & \multicolumn{2}{|c|}{$\begin{array}{c}\text { Unstandardized } \\
\text { Coefficients }\end{array}$} & $\begin{array}{c}\text { Standardized } \\
\text { Coefficients }\end{array}$ & \multicolumn{1}{c|}{ Sig. } \\
\cline { 2 - 4 } & \multicolumn{1}{|c|}{ B } & \multicolumn{1}{c|}{ Std. Error } & \multicolumn{1}{c|}{ Beta } & & \\
\hline \multirow{2}{*}{ (Constant) } &,- 034 &, 048 & &,- 702 &, 486 \\
1 &, 022 &, 057 &, 047 &, 386 &, 701 \\
X1 &, 001 &, 000 &, 412 & 3,426 &, 001 \\
X2 &, 106 &, 044 &, 286 & 2,383 &, 021 \\
\hline
\end{tabular}

a. Dependent Variable: $Y$

Sumber : Hasil Output SPSS 20 (data diolah)

Berdasarkan tabel di atas maka persamaan regresinya yaitu :

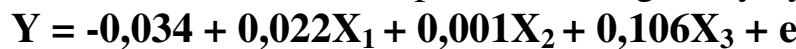

$$
\begin{aligned}
& \text { Di mana : } \quad \mathbf{Y}=\text { Cash Holding } \\
& \mathbf{X}_{\mathbf{1}}=\text { Growth Opportunity } \\
& \mathbf{X}_{2}=\text { Cash Conversion Cycle } \\
& \mathbf{X}_{\mathbf{3}}=\text { Net Profit } / \text { Loss } \\
& \text { e }=\text { Error Term }
\end{aligned}
$$

Koefisien Determinasi $\left(\mathbf{R}^{2}\right)$

\section{Hasil Uji Koefisien Determinasi $\left(\mathbf{R}^{2}\right)$}

Model Summary ${ }^{\mathrm{D}}$

\begin{tabular}{|l|r|r|r|r|}
\hline Model & $\mathrm{R}$ & $\mathrm{R}$ Square & \multicolumn{1}{|c|}{$\begin{array}{c}\text { Adjusted } \mathrm{R} \\
\text { Square }\end{array}$} & $\begin{array}{c}\text { Std. Error of the } \\
\text { Estimate }\end{array}$ \\
\hline 1 &, $475^{\mathrm{a}}$ &, 226 &, 184 &, 108248 \\
\hline
\end{tabular}

a. Predictors: (Constant), X3, X2, X1

b. Dependent Variable: $Y$

Sumber : Hasil Output SPSS 20 (data diolah)

Berdasarkan tabel di atas diperoleh nilai koefisien korelasi $\left(\mathrm{R}^{2}\right)$ sebesar 0,226 atau 22,6\%. Artinya, variabel independen (Growth Opportunity, Cash Conversion Cycle dan Net Profit/Loss) mempunyai pengaruh terhadap Cash Holding pada perusahaan manufaktur kelompok Makanan dan Minuman yang terdaftar di Bursa Efek Indonesia sebesar 22,6\% sedangkan sisanya $77,4 \%$ dipengaruhi oleh variabel lain yang tidak terungkap atau tidak diteliti dalam penelitian ini. 
Uji Signifikasi Simultan (Uji F)

Hasil Uji Signifikasi Simultan (Uji F)

ANOVA $^{\mathrm{a}}$

\begin{tabular}{|c|c|c|c|c|c|}
\hline Model & Sum of Squares & $\overline{D f}$ & Mean Square & $\mathrm{F}$ & Sig. \\
\hline Regression &, 191 & 3 &, 064 & 5,442 &, $002^{D}$ \\
\hline Residual & ,656 & 56 & 012 & & \\
\hline Total & ,847 & 59 & & & \\
\hline
\end{tabular}

a. Dependent Variable: $Y$

b. Predictors: (Constant), X3, X2, X1

Sumber :Hasil Output SPSS 20 (data diolah)

Tabel di atas menyatakan bahwa nilai F-hitung sebesar 5,442 dengan signifikansi 0,002 dan nilai $\mathrm{F}$ tabel sebesar 2,769 dengan signifikansi 0,05 $(5,442>2,769)$. Karena F-hitung $>$ F-tabel dan sig. $\mathrm{F}<0,05$ maka $\mathrm{H}_{0}$ ditolak dan $\mathrm{H}_{4}$ diterima. Dengan demikian, Growth Opportunity, Cash Conversion Cycle dan Net Profit/Loss secara simultan berpengaruh signifikan terhadap Cash Holding.

\section{Uji Signifikasi Parsial (Uji t)}

\section{Hasil Uji Signifikansi Parsial (Uji t)}

Coefficients $^{\mathrm{a}}$

\begin{tabular}{|r|r|r|r|r|r|}
\hline \multirow{2}{*}{ Model } & \multicolumn{2}{|c|}{$\begin{array}{c}\text { Unstandardized } \\
\text { Coefficients }\end{array}$} & $\begin{array}{c}\text { Standardized } \\
\text { Coefficients }\end{array}$ & \multirow{2}{*}{ Sig. } \\
\cline { 2 - 4 } & \multicolumn{1}{|c|}{ B } & \multicolumn{1}{c|}{ Std. Error } & \multicolumn{1}{c|}{ Beta } & & \\
\hline \multirow{2}{*}{ (Constant) } &,- 034 &, 048 & &,- 702 &, 486 \\
1 &, 022 &, 057 &, 047 &, 386 &, 701 \\
X1 &, 001 &, 000 &, 412 & 3,426 &, 001 \\
X2 &, 106 &, 044 &, 286 & 2,383 &, 021 \\
\hline
\end{tabular}

a. Dependent Variable: $Y$

Sumber : Hasil Output SPSS 20 (data diolah)

Berdasarkan tabel di atas dapat dijelaskan beberapa hal sebagai berikut :

- Growth Opportunity $\left(\mathrm{X}_{1}\right)$ memiliki nilai t-hitung sebesar 0,386 dengan signifikansi sebesar 0,701, sedangkan nilai t-tabel sebesar 2,003 dengan signifikansi $0,05(0,386<2,004)$. Karena t-hitung $<\mathrm{t}$-tabel dan sig. $\mathrm{t}<$ 0,05 maka $\mathrm{H}_{0}$ diterima dan $\mathrm{H}_{1}$ ditolak. Dengan demikian, dapat disimpulkan bahwa Growth Opportunity tidak berpengaruh terhadap Cash Holding.

- Cash Conversion Cycle $\left(\mathrm{X}_{2}\right)$ memiliki nilai t-hitung sebesar 3,426 dengan signifikansi sebesar 0,001, sedangkan nilai t-tabel sebesar 2,003 dengan signifikansi $0,05(3,426>2,003)$. Karena t-hitung $<$ t-tabel dan 
sig. $\mathrm{t}>0,05$ maka $\mathrm{H}_{0}$ ditolak dan $\mathrm{H}_{2}$ diterima. Dengan demikian, dapat disimpulkan bahwa Cash Conversion Cycle berpengaruh positif signifikan terhadap Cash Holding.

- Net Profit/Loss $\left(\mathrm{X}_{3}\right)$ memiliki nilai t-hitung sebesar 2,383 dengan signifikansi sebesar 0,021, sedangkan nilai t-tabel sebesar 2,003 dengan signifikansi 0,05 $(2,383>2,003)$. Karena t-hitung $<\mathrm{t}$-tabel dan sig. $\mathrm{t}<$ 0,05 maka $\mathrm{H}_{0}$ ditolak dan $\mathrm{H}_{3}$ diterima. Dengan demikian, dapat disimpulkan bahwa NetProfit/Loss berpengaruh positif signifikan terhadap Cash Holding.

\section{PEMBAHASAN}

\section{Pengaruh Growth Opportunity terhadap Cash Holding}

Growth Opportunity memiliki nilai t-hitung sebesar 0,386 dengan signifikansi sebesar 0,701, sedangkan nilai t-tabel sebesar 2,003 dengan signifikansi $0,05(0,386<2,004)$. Karena t-hitung $<\mathrm{t}$-tabel dan sig. $\mathrm{t}<$ 0,05 maka $\mathrm{H}_{0}$ diterima dan $\mathbf{H}_{1}$ ditolak. Dengan demikian, dapat disimpulkan bahwa Growth Opportunity tidak berpengaruh terhadap Cash Holding. Hal ini mengindikasikan bahwa besar kecilnya nilai Growth Opportunity belum cukup menentukan apakah perusahaan melakukan penahanan kas dalam jumlah besar. Hasil penelitian ini menunjukkan bahwa perusahaan tidak terlalu mempertimbangkan tingkat Growth Opportunity dalam melakukan penahanan kas.

Dengan demikian, penelitian ini tidak sejalan dengan Trade-off Theory yang menyatakan bahwa perusahaan dengan tingkat pertumbuhan yang tinggi akan melakukan penahanan kas dalam jumlah besar untuk membiayai pertumbuhannya, karena manfaat yang didapatkan perusahaan lebih besar daripada biaya yang ditimbulkan dari memegang kas. Hasil penelitian ini berbeda dengan penelitian William danFauzi (2013) dan Marfuah dan Zulhimi (2014) yang menyatakan bahwa Growth Opportunity berpengaruh positif terhadap Cash Holding.

Growth Opportunity tidak berpengaruh terhadap Cash Holding dikarenakan perbedaan tingkat pertumbuhan yang dimiliki perusahaan dalam penelitian dan kemudian perusahaan juga lebih memilih sumber dana lain dibandingkan menggunakan kas yang ada di perusahaan untuk mendanai Growth Opportunity, misalnya perusahaan membuat perjanjian hutang dengan perusahaan lain. 
Penulis juga menemukan adanya beberapa perusahaan sampel yang menunjukkan data penurunan nilai Growth Opportunity namun nilai Cash Holding mengalami kenaikan. Misalnya PT.Tiga Pilar Sejahtera food Tbk dari tahun 2013 ke tahun 2014 memiliki nilai Growth Opportunity masingmasing $(0,476 ; 0,267)$ dan nilai Cash Holding masing- masing $(0,063$; $0,165)$.

\section{Pengaruh Cash Conversion Cycle terhadap Cash Holding}

Cash Conversion Cycle memiliki nilai t-hitung sebesar 3,426 dengan signifikansi sebesar 0,001, sedangkan nilai t-tabel sebesar 2,003 dengan signifikansi $0,05(3,426>2,003)$. Karena t-hitung $<$ t-tabel dan sig. $\mathrm{t}>0,05$ maka $\mathrm{H}_{0}$ ditolak dan $\mathbf{H}_{2}$ diterima. Dengan demikian, dapat disimpulkan bahwa Cash Conversion Cycle berpengaruh positif signifikan terhadap Cash Holding.

Hasil penelitian ini sejalan dengan Pecking Order Theory bahwa semakin lama siklus konversi kas maka semakin besar juga kebutuhan pendanaan internal sehingga perusahaan cenderung menahan kas dalam jumlah besar. Hasil penelitian ini juga didukung oleh penelitian William dan Fauzi (2013) yang menyatakan bahwa Cash Conversion Cycle berpengaruh positif terhadap Cash Holding.

Penulis juga menemukan adanya beberapa perusahaan sampel yang menunjukkan data Cash Conversion Cycle dengan Cash Holding yang berhubungan positif. Misalnya PT. Tiga Pilar Sejahtera food Tbk tahun 2012 ke tahun 2013 memiliki nilai Cash Conversion Cycle masing-masing $(139,927 ; 148,965)$ dan nilai Cash Holding masing-masing $(0,026$; $0,063)$.

\section{Pengaruh Net Profit/Loss terhadap Cash Holding}

Net Profit/Loss memiliki nilai t-hitung sebesar 2,383 dengan signifikansi sebesar 0,021, sedangkan nilai t-tabel sebesar 2,003 dengan signifikansi 0,05 (2,383 >2,003). Karena t-hitung $<\mathrm{t}$-tabel dan sig. $\mathrm{t}<0,05$ maka $\mathrm{H}_{0}$ ditolak dan $\mathbf{H}_{3}$ diterima. Dengan demikian, dapat disimpulkan bahwa Net Profit/Loss berpengaruh positif secara signifikan terhadap Cash Holding.

Penelitian ini sejalan dengan Trade-off Theory yang menyatakan bahwa perusahaan yang mengalami laba memegang kas dalam jumlah banyak karena manfaat yang didapatkan perusahaan lebih besar daripada biaya yang ditimbulkan dari memegang kas. Hasil penelitian ini tidak 
didukung oleh hasil penelitian lain karena pengaruh Net Profit/Loss terhadap Cash Holding belum pernah diteliti oleh peneliti sebelumnya.

Penulis juga menemukan adanya beberapa perusahaan sampel yang menunjukkan data Net Profit/Loss dengan Cash Holding yang berhubungan positif. Misalnya PT. Tiga Pilar Sejahtera food Tbk tahun 2013 ke tahun 2014 yang mengalami laba dan nilai Cash Holding meningkat masing-masing $(0,063 ; 0,165)$.

\section{KESIMPULAN DAN SARAN}

\section{Kesimpulan}

Berdasarkan hasil penelitian dan pembahasan pengaruh Growth Opportunity, Cash Conversion Cycle dan Net Profit/Loss terhadap Cash Holding yang dilakukan terhadap 15 sampel perusahaan manufaktur kelompok Makanan dan Minuman yang terdaftar di Bursa Efek Indonesia periode 2012-2015, maka diperoleh kesimpulan sebagai berikut:

1. Variabel Growth Opportunity tidak berpengaruh terhadap Cash Holding.

2. Variabel Cash Conversion Cycle berpengaruh positif signifikan terhadap Cash Holding.

3. Varabel Net Profit/Loss berpengaruh positif signifikan terhadap Cash Holding.

4. Variabel Growth Opportunity, Cash Conversion Cycle dan Net Profit/Loss secara simultan berpengaruh signifikan terhadap Cash Holding.

\section{Saran}

Berdasarkan kesimpulan di atas maka penulis memberikan saran sebagai berikut :

1. Peneliti selanjutnya diharapkan dapat mengembangkan penelitian ini dengan menambahkan variabel lain-lain yang kemungkinan mempengaruhi tingkat Cash Holding.

2. Para praktisi khususnya manajer perusahaan diharapkan agar mempertimbangkan faktor-faktor yang mempengaruhi kebijakan Cash Holding hasil dari penelitian ini. Namun, para praktisi juga diharapkan tidak hanya terpaku pada hasil penelitian ini dalam menentukan kebijakan Cash Holding. Sebab terdapat faktor-faktor lain yang perlu dipertimbangkan dalam menentukan kebijakan Cash Holding. 


\section{DAFTAR PUSTAKA}

Brigham, E.F., Houston, J.F., 2006. Manajemen Keuangan, Edisi Kedelapan. Jakarta : Erlangga.

Bigelli, Marco and Vidal, Javier S, 2009. Cash Holdings in Private Firms.

Deitiana,T.2011. Pengaruh Rasio Keuangan, Pertumbuhan Penjualan, dan Dividen Terhadap Harga Saham.Jurnal Bisnis dan Akuntansi. Vol. 13,No. 1

Ferreira, Miguel and Vilela, Antonio, 2004. Why Do Firm Hold Cash? Evidence from EMU Countries. European Financial Management, vol. 10 no. 2 295-319.

Firth, Michael . 2008. Leverage and investement under a state-owned bank lending environment: evidence from China, Journal of Corporate Finance, No.14, pp.642653.

Gill, Amarjit and Shah, Charul, 2012. Determinants of Corporate Cash Holdings : Evidence from Canada. Journal International of Economics and Finance vol.4 no.1.

Ghozali. Imam. 2006. Aplikasi Analisis Multivariate dengan Program SPSS. Semarang: Badan Penerbit Universitas Diponegoro.

Hanafi, Mamduh M. 2014. Manajemen keuangan. Yogyakarta: BPFE-Yogyakarta.

Harmono, 2009. Manajemen Keuangan. Jakarta: Bumi Aksara.

Hery, (cand). 2013. Teori Akuntansi Suatu Pengantar. Jakarta: Lembaga Penerbit Fakultas Ekonomi Universitas Indonesia.

Horngren, C. T., Harisson, W. T, Robinson, M. A, dan Secokusumo, T. H. 1994. Akuntansi di Indonesia. Jakarta: Salemba Empat.

Ikatan Akuntansi Indonesia. 2009. Pernyataan Standar Akuntansi Keuangan (PSAK) No.2, Penerbit Salemba Empat, Jakarta.

Irham, Fahni.2014. Manajemen Keuangan Perusahaan dan Pasar Modal, Edisi Pertama. Jakarta : Mitra Wacana Media.

Mai, Muhammad Umar., 2006,Analisis Variabel-Variabel yang Mempengaruhi Struktur Modal Pada Perusahaan-Perusahaan LQ-45 di Bursa Efek Jakarta, Ekonomika, Hal. 228- 245.Politeknik Negeri, Bandung.

Marfuah, dan Ardan Zulhilmi. (2014). Pengaruh Growth Opportunity, Net Working Capital, Cash Conversion Cyrcle dan Leverage Terhadap Cash Holding Perusahaan. Jurnal Universitas Islam Indonesia.

Opler et al, 1999. The Determinants and Implications of Corporate Cash Holdings. Journal of Financial Economics Vol 52, 3-46.

Syamsuddin, Lukman. 1994. Manajemen Keuangan Perusahaan, Edisi Kedua. Jakarta : PT Raja GraFindo Persada.

Syarief,Moch.Ednan,dan Ita Prihatining Wilujeng.(2009).Cash Conversion Cyrcle dan Hubungannya dengan Ukuran Perusahaan, Profitabilitas dan Manajemen Modal Kerja.Jurnal Ekonomi dan Bisnis,Tahun 14 Nomor 1 Maret 2009.

Wijaya, Anggita Langgeng, Bandi, dan Sri Hartoko. (2010). Pengaruh Kualitas Akrual dan Leverage Terhadap Cash Holding Perusahaan. Jurnal Akuntansi dan Keuangan. Vol 7-No 2, Desember 2010.

William, dan Syarief Fauzi.(2013). Analisis Pengaruh Growth Opportunity, Net Working Capital dan Cash Conversion Cyrcle terhadap Cash Holdings Perusahaan Sektor Pertambangan.JurnalEkonomidan Keuangan,Vol 1, No.2.

www.idx.co.id 